\title{
Factor Influencing Unplanned Buying Behavior of Untapped Market
}

\author{
Amandeep Kaur ${ }^{1}$, Megha ${ }^{2}$ \\ ${ }^{1,2}$ (Budha college of Management, Ramba, Karnal,India)
}

\begin{abstract}
In the current scenario where everyone wants to head the market, it is very important for the marketers to understand the consumer buying behaviour. To chalk out the marketing strategies for their companies, it is crucial for managers to have a proper knowledge and understanding of buyer's behaviour. When a large numbers of consumer buys the product of a particular company that symbolize how well they had planned their marketing strategies. The kinship between consumer behaviour and marketing strategy is stressed because the success of companies marketing strategies totally calculated on the basis of managers understanding of buying behaviour. Before taking any buying decision consumer go through various psychological processes in realizing their demands, search out the paths to figure out these demands (say, by comparing the product brands, or actually buying the product). The study revolves around unplanned buying behaviour of low involvement products, refers to unplanned buying decisions made by untapped market i.e. rural consumer. This work is an effort to explore the factors that motivates unplanned buying behavior - low price, promotional schemes, opinion leaders and store display. The research is based on primary data collected from untapped consumers of 4 districts of Haryana, with the help of well structured questionnaire. The statistical tools applied the study is Mean Score, Standard Deviation, Correlation and ' $t$ ' Test. Findings of the study indicate that comments of reference group (opinion leaders) and Store display influence impulse buying. [1] If family members or friends go with the consumer, they motivate him/her to be impulsive by suggesting prominent \& existing brands.
\end{abstract}

Keywords - consumer behaviour, factors influencing, low involvement, unplanned buying, untapped market.

\section{INTRODUCTION}

"Buy, buy, says the sign in the shop window; Why, why, says the junk in the yard." Popular saying of, Paul McCartney is suitable for everyone who indulge in unplanned buying. Everyone has such kind of shopping experience once in a while. "Behavior is the mirror in which everyone shows their image". [2] (Johann Wolfgang von Goethe, cited by Ajzen, 1988). This study extends the concept of Goethe's quote: not only is behaviour is the mirror in which everyone shows their image, it also reflects the image of an individual's surroundings and the situation in which the behaviour occurs. In a country like India, where rural market is untapped as well as in its developing stage it becomes significant to study entitled "Factors Influencing Unplanned Buying Behaviour of Untapped Market". Rural consumer is totally a different consumer in the rural market scenario, being influenced by rationality, personal experience, and the level of utility that is derived from the consumption, which are being influenced by the changing tastes and preferences of the younger generation. The clever and gimmicky advertisements do not work out with rural consumers. This kind of scenario exists because rural buyers prefer to buy products on the basis of purchasing experience of their friends, relatives, neighbors and sometimes their own past experience of a particular brand or product. And Apart from this other important factors which mold the purchasing decisions are accessibility of products and their quality. Most of the times pre planned buying is affected by impulsive buying transaction. Impulse buying is an instant buying decision that is not planned in advance. Pricing factor, store factor and affordability always have positive impact on unplanned buying. A product with reduced price is gives birth to instant buying decisions. As well as store factor is concerned ambience always induce buyer to be impulsive. Prominent factors like shelf display, courtesy and point of purchase offer provokes impulse buying. [1]Marketers for rural India should put more efforts by creating attractive and eye catching POS offers \& product display providing information regarding new products. Sometimes the positive experience of opinion leaders also drive unplanned buying in untapped market. 


\section{REVIEW OF LITERATURE}

[3] Husnain and Akhtar (2016) the study examined the motivational factors behind impulsive buying and different approaches regarding packaging and labeling of FMCG. Findings of the study indicate that branding has a significant impact and predict good proportion of variance in impulsive buying behaviour.

[4] Darda and Saxena (2015) investigated online purchasing behaviour of urban and rural consumers. The study aimed to understand the functioning of online purchasing and different purchasing behaviour of rural and urban consumers. The study found that due to lack of information, rural consumers are not much attracted towards online purchasing and in some cases companies do not deliver the products in rural areas. Sometimes consumers are not willing to buy high priced products online.

[5] Manohora and Manjunathak (2015) studies the instability in consumers impulsive buying behaviour and applicability of black box theme to impulsive buying while purchasing FMCGs. Findings of the study revealed that brand, family, past experience and price are highly influencing factors and black box theory is not completely applicable because observation and estimation can be made by retailers.

[6] Bashar Abu, et al (2013) investigated the effect of demographic factors on the impulse buying behaviour. [6] Inter-variable correlation and regression analysis were used in the study. The [6] results showed that demographic factors, such as the disposable income and age, positively affect impulse buying behaviour. [6] However, Educational qualification and gender produced marginal association with impulsive buying behaviour.

[7] Rana, S. (2012) investigated [7] the effect of Education, Income and Gender on the impulsive buying tendency among Indian consumers. A sample of 450 shoppers at selected authorized retail outlets and shopping mall in Patiala were taken. The results of ANOVA at 5\% level of significance [7] showed that Education and Income of the consumers were more likely to influence impulsive buying than the Gender of the customers. Retailers may use the findings of the study to improve their merchandise assortment and improve the shopping environment.

[8] Tauseef (2011) attempted [8] to find the variables/factors that affect customer impulsive buying behaviour in FMCG sector considering retail market in India. The impact of various impulse buying factors like sales and promotions, placement of products, window merchandising, effective price strategy etc., on customer buying behaviour have been analyzed. A hypothetical model was created in this paper, which had been taken into consideration for our research work on impulse buying behaviour of consumers.

[9] Mattila and Wirtz (2008) highlighted that social factors influence impulse buying. Social factors include two types: store employees and other customers. Social factor (e.g. employee friendliness) was found to directly influence impulse buying. Store managers might be able to reduce the negative effect of crowding by training their employees to be extra friendly at busy times.

[10] Lan Xia and Kent B. Monroe (2008) examined how consumer's prior purchase goals interact with promotion characteristics to influence their perceptions of price promotions and their willingness to buy.

[11] Lee (1991) conducted a study of the influence of shopper type and mood on impulse purchasing behaviour. This study considered two influential factors: shopper type (recreational Vs economic) and mood (positive Vs negative). Both have shown a close relationship with impulse purchasing behaviour. It revealed that comparing shopper type and mood, shopper type was found to be more influential than mood on impulse purchasing behaviour. It was found that, interaction effect between shopper type and mood was found marginally significant.

[12] Engel and Blackwell (1982) impulse buying is an action undertaken without previously having been consciously recognized or a buying intention formed prior to entering the store. Based upon the different description, we conclude that impulse buying involves hedonic purchase decisions which are made inside a store and excludes the reminder purchasing activities.

\subsection{OBJECTIVES OF THE STUDY}

\section{RESEARCH METHODOLOGY}

1) To analyze the factors influencing impulsive buying behaviour of rural consumers regarding low involvement products; 
2) To measure the impact of demographics variables on the unplanned buying behaviour of consumers regarding low involvement products;

3.2 HYPOTHESES OF THE STUDY

Ho1: There is no significant difference between unplanned/impulsive buying behaviour and gender.

Ho2: There is no significant difference between unplanned/impulsive buying behaviour and marital status.

3.3 SCOPE OF THE STUDY

The selection of customers was confined to the state of Haryana and data was collected from rural areas of Four Districts of Haryana viz. Karnal, Kurukshetra, Ambala and Panipat.

3.4 SAMPLE SIZE

It is an empirical study. The sample of the study is based upon the initial pilot study. Sampling technique is convenience. The study has utilized a sample of 125 customers from each selected district of Haryana.

3.5 STATISTICAL TOOLS USED

In order to meet the desired objectives as described above and to verify the necessary underlying hypotheses, necessary statistical tools were applied to draw logical and scientific conclusions and inferences. Some of the basic tools were Mean Score, Standard Deviation, Correlation and' $t$ ' Test.

\section{RESUlts AND Discussions}

Impulsive buying decision divulges routine shopping practice. This is basically more of emotional buying where unthoughtfulness is very mellow. It happens just because one wants to elude or reason being the product is a trinket.

TABLE I. Unplanned/Impulsive Buying Decisions on the basis of Gender

\begin{tabular}{|c|c|c|c|c|c|}
\hline Variables & Gender & $\mathbf{N}$ & Mean Scores & Std. Deviation & t-Value \\
\hline \multirow{2}{*}{ Low Pricing } & Male & 265 & 19.15 & 2.43 & \multirow{2}{*}{$9.42^{* *}$} \\
\cline { 2 - 5 } & Female & 235 & 17.20 & 2.19 & \\
\hline \multirow{2}{*}{ Opinion Leaders } & Male & 265 & 29.17 & 3.90 & \multirow{2}{*}{$12.26^{* *}$} \\
\cline { 2 - 5 } & Female & 235 & 33.01 & 3.10 & \\
\hline \multirow{2}{*}{ Store Display } & Male & 265 & 11.81 & 3.63 & \multirow{2}{*}{$12.15^{* *}$} \\
\cline { 2 - 5 } & Female & 235 & 15.02 & 2.17 & \multirow{2}{*}{$8.6^{* *}$} \\
\hline \multirow{2}{*}{ Sales Promotion Schemes } & Male & 265 & 31.53 & 2.85 & 3.61 \\
\cline { 2 - 5 } & Female & 235 & 29.03 & \\
\hline
\end{tabular}

**--Significant at $1 \%$

The analysis suggested that for all the variables the hypotheses under study was rejected as calculated ' $\mathrm{t}$ ' value was highly significant $(\mathrm{p}<.01)$. The study indicated that there is significant difference between rural consumer impulsive buying behaviour regarding low involvement products and their gender.

TABLE II. Unplanned/Impulsive Buying Decisions on the basis of Marital Status

\begin{tabular}{|c|c|c|c|c|c|}
\hline Variables & $\begin{array}{c}\text { Marital } \\
\text { Status }\end{array}$ & $\mathbf{N}$ & Mean Scores & Std. Deviation & \multirow{2}{*}{ t-Value } \\
\hline \multirow{2}{*}{ Low Pricing } & Married & 284 & 18.76 & 2.70 & \multirow{2}{*}{$5.70^{* *}$} \\
\cline { 2 - 5 } & Unmarried & 216 & 17.54 & 2.08 & \\
\hline \multirow{2}{*}{ Opinion Leaders } & Married & 284 & 28.99 & 2.94 & \multirow{2}{*}{$14.77^{* *}$} \\
\cline { 2 - 5 } & Unmarried & 216 & 33.58 & 3.79 & \multirow{2}{*}{$21.04^{* *}$} \\
\hline \multirow{2}{*}{ Store Display } & Married & 284 & 11.32 & 2.90 & 1.99 \\
\cline { 2 - 6 } & Unmarried & 216 & 15.94 & 3.55 & \multirow{2}{*}{$3.32^{* *}$} \\
\hline Sales Promotion Schemes & Married & 284 & 29.92 & \\
\hline
\end{tabular}

Special Issue - AETM'16

$9 \mid$ Page 


\begin{tabular}{|l|c|c|c|c|c|}
\hline & Unmarried & 216 & 30.93 & 3.26 & \\
\hline$* *_{-- \text {Significant at } 1 \%}$
\end{tabular}

It is evident from the table 2 that the calculated $t$ value of the consumer impulsive buying decision on the basis of marital status 5.70 (significant at 1 per cent). The value indicates there is significant difference between consumers purchase decision on the basis of low pricing with respect to marital status is rejected. The calculated $t$ value of the consumer purchase decision on the basis of marital status 14.77 (significant at 1 per cent). The value indicates there is significant difference between consumers purchase decision through opinion leaders (reference group) with respect to marital status is rejected. The calculated $t$ value of the consumer purchase decision on the basis of marital status 21.04 (significant at 1 per cent). The value indicates there is significant difference between consumers purchase decision in store display with respect to marital status is rejected. The calculated $t$ value of the consumer purchase decision on the basis of marital status 3.32 (significant at 1 per cent). The value indicates there is significant difference between consumers purchase decision in sales promotion schemes with respect to marital status is rejected.

TABLE III. Correlation Analysis

\begin{tabular}{|c|c|c|}
\hline Sr. No. & Variables & Impulsive Buying Behaviour \\
\hline 1. & Low Pricing & $0.59^{* *}$ \\
\hline 2. & Sales Promotional Activities & $0.62^{* *}$ \\
\hline 3. & Store Display & $0.68^{* *}$ \\
\hline 4. & Advertising Activities & $0.56^{* *}$ \\
\hline 5. & Brand Awareness & $0.22^{*}$ \\
\hline 6. & Opinion Leader & $0.72^{* *}$ \\
\hline
\end{tabular}

$* *$ Correlation at $1 \%$

* Correlation at $5 \%$

The perusal of the table 3 suggested that there is a positive and significant correlation between low pricing, sales promotion, store display, advertising activities, brand awareness, opinion leaders and Impulsive buying behaviour of rural consumers for low involvement products.

\section{Conclusion}

The findings of the study revealed that opinion leaders and store display are the triggering factors for creating an unplanned/impulsive buying behaviour among the rural consumers, whereas brand awareness is the only variable having less influence comparatively for purchasing low involvement products. Point of purchase offers, shelf display, courtesy of sales executives and opinion leaders plays a decisive role in unplanned buying. A significant difference was found between rural consumer buying behaviour regarding low involvement products and their gender as well as marital status. The study has not covered the post purchase behaviour of unplanned buyers. However, it's worth to know either they are satisfied with their impulse purchase decisions or not. On the other hand the researcher has taken into consideration only few factors as there are numerous factors affecting impulsive buying behaviour. Further research is suggested to discover these divisors. As far as the managerial implication of this study is concerned, if marketer wants to encourage unplanned buying, they should try to highlight the positive impact of impulse buying through various promotional activities and effective shop presentation. 


\section{REFERENCES}

[1] http://www.google.co.in/url?url=http://www.slideshare.net/tushaarjoshi/factors-affecting-buying-behavior-at-the-point-of sale.

[2] J.W. Ajzen, "Names, Brands, Branding: Beyond the Signs, Symbols, Products and Services", Journal of Product \& Brand Management, 12(2), 1988, 117- 118

[3] M. Husnain and M. W. Akhtar, "Impact of Branding on Impulse Buying Behavior: Evidence from FMCG's Sector Pakistan” International Journal of Business Administration, 7 (1), 2016.

[4] P. Darda and V. D. Saxena, "Online market: a comparative study of consumer behaviour from rural and urban areas" International journal of logistics \& supply chain management perspectives, Pezzottaite Journals, 4, (1), 2015.

[5] Manohora and Manjunathak, "A study on factors influencing on consumers Impulsive buying behaviour towards fmcgs in Different day sessions", International Journal of Business Administration, 7 (1), 2015.

[6] A. Bashar, I. Ahmad and M. Wasiq, "A study of influence of demographic factors on consumer impulse buying behavior", Journal of Management Research, 13(3), 2013, 145.

[7] S. Rana, "Effect of Education, Income and Gender on Impulsive Buying Among Indian Consumer an Empirical Study of Readymade Garment Customers", 1(12), 2012.

[8] A.Tauseef, "The Impulse Buying Behaviour of Consumers for the FMCG Products in Jodhpur", Australian Journal of Basic and Applied Sciences, 5(11), 2011, 1704- 1710.

[9] A. S. Mattila and J. Wirtz, "The role of store environmental stimulation and social factors on impulse purchasing", Journal of Services Marketing, 22(7), 2008, 562-567.

[10] L. Xia and K. B. Monroe, "Impulsive Buying: Its Relation To Personality Traits and Cues and Store Patronage", Advances in Consumer Research, 27, 2008, 179-185.

[11] D.W Lee, "The Influence of Shopper Type and Mood on Impulse Purchasing Behaviour", Dissertation Abstracts International, 51(12), 1991, 4201-4202.

[12] F. J. Engel, and B. D. Roger, Consumer Behaviour, (Tokyo: The Dryden Press, 1982). 